\title{
Basin-scale water-balance dataset (BSWB): an update
}

\author{
Martin Hirschi and Sonia I. Seneviratne \\ Institute for Atmospheric and Climate Science, ETH Zurich, Universitätstrasse 16, 8092 Zürich, Switzerland \\ Correspondence to: Martin Hirschi (martin.hirschi@env.ethz.ch) \\ Received: 21 July 2016 - Discussion started: 24 October 2016 \\ Revised: 24 February 2017 - Accepted: 28 February 2017 - Published: 30 March 2017
}

\begin{abstract}
This paper presents an update of a basin-scale diagnostic dataset of monthly variations in terrestrial water storage for large river basins worldwide (BSWB v2016, doi:10.5905/ethz-1007-82). Terrestrial water storage comprises all forms of water storage on land surfaces, and its seasonal and inter-annual variations are mostly determined by soil moisture, groundwater, snow cover, and surface water. The dataset presented is derived using a combined atmospheric and terrestrial water-balance approach with conventional streamflow measurements and reanalysis data of atmospheric moisture flux convergence. It extends a previous, existing version of the dataset (Mueller et al., 2011) temporally and spatially.
\end{abstract}

\section{Introduction}

Terrestrial water storage (TWS) plays a key role in the hydrological cycle. It encompasses all water stored on land surfaces, and its seasonal and inter-annual variations are determined by soil moisture, groundwater, snow cover, and surface water. Soil moisture, especially, contributes to landatmosphere coupling in an essential way (e.g. Koster et al., 2006; Seneviratne et al., 2006, 2010; Hirschi et al., 2011; Miralles et al., 2014; Guillod et al., 2015). In particular, it is important for numerical weather prediction (e.g. Beljaars et al., 1996; Drusch, 2007; Orth et al., 2016) and seasonal forecasting (e.g. Koster et al., 2000; van den Hurk et al., 2010), as well as for simulations of present and future climate (e.g. Shukla and Mintz, 1982; Milly and Dunne, 1994; Koster et al., 2009; Seneviratne et al., 2013).

Despite recent activities in assembling in situ soil moisture observations (Dorigo et al., 2013), global coverage remains limited. This is even more the case for in situ observations of the other components of TWS. Remote sensing can help to increase the spatial coverage with observations. For soil moisture, the European Space Agency (ESA) Climate Change Initiative (CCI, http://www. esa-soilmoisture-cci.org) provides a long-term global soil moisture product from merging data from active and passive microwave sensors (Liu et al., 2012). However, penetration depth is limited to the top few centimetres of the soil
(Owe and Van de Griend, 1998). On the other hand, remotesensing-based measurements of TWS from the Gravity Recovery and Climate Experiment (GRACE; Tapley et al., 2004; Ramillien et al., 2008; Humphrey et al., 2016) only go back to 2002. Thus, for further retrospective evaluation of TWS, alternative approaches are required.

Here, we rely on a combination of streamflow measurements (relatively broadly available) and an observationassimilating atmospheric reanalysis system to diagnose TWS variations on a basin scale (e.g. Seneviratne et al., 2004; Hirschi et al., 2006a). This allows for an evaluation of TWS variations in gauged river basins worldwide and over a longer time period (mostly limited by the availability of streamflow data). The basin-scale water-balance dataset of monthly TWS variations (BSWB v2016) presented here extends a previous version of the dataset (Mueller et al., 2011; hereafter referred to as BSWB v2011; data available at www.iac. ethz.ch/url/bswb) temporally and spatially.

\section{Methodology}

The method used to derive the BSWB v2016 dataset is based on publications describing previous versions of the data (Seneviratne et al., 2004; Hirschi et al., 2006a; Mueller et al., 2011). For a given river basin, the terrestrial water balance can be expressed as 


$$
\left\{\frac{\overline{\partial S}}{\partial t}\right\}=\{\bar{P}-\bar{E}\}-\{\bar{R}\},
$$

where $S$ represents the TWS of the given basin, $P$ the precipitation, $E$ the evapotranspiration, and $R$ the measured streamflow, which is assumed to include both the surface and the groundwater run-off of the area. The overbar denotes a temporal average (i.e. monthly means) and \{\} a space average over the basin.

Neglecting the contribution of the liquid and solid water in clouds (Peixoto and Oort, 1992), the atmospheric water balance for the same area can be expressed as

$$
\left\{\overline{\frac{\partial W}{\partial t}}\right\}=-\left\{\overline{\nabla_{H} \cdot \boldsymbol{Q}}\right\}-\{\bar{P}-\bar{E}\},
$$

where $W$ represents the column storage of water vapour and $\boldsymbol{Q}$ the vertically integrated two-dimensional water vapour flux. The operator $\left(\nabla_{H} \cdot\right)$ denotes the horizontal divergence. Eliminating the term $\{\bar{P}-\bar{E}\}$ in Eqs. (1) and (2) results in the combined atmospheric and terrestrial water-balance equation:

$$
\left\{\overline{\frac{\partial S}{\partial t}}\right\}=-\left\{\overline{\frac{\partial W}{\partial t}}\right\}-\left\{\overline{\nabla_{H} \cdot \boldsymbol{Q}}\right\}-\{\bar{R}\} .
$$

The monthly variations in TWS of the studied basin can thus be expressed as the sum of three terms only: the change in atmospheric water vapour content, the water vapour flux convergence, and the measured river streamflow. The term $\{\overline{\partial W / \partial t}\}$ is usually negligible for annual means but not for monthly means, particularly during the spring and fall seasons (Rasmusson, 1968; Seneviratne et al., 2004).

\section{Data sources}

\subsection{Reanalysis data}

The vertically integrated atmospheric moisture flux divergence and water vapour content are taken from the ERAInterim reanalysis product (Dee et al., 2011) of the European Centre for Medium-Range Weather Forecasts (ECMWF).

ERA-Interim is produced with a 2006 version of the IFS (Integrated Forecasting System, Cy31r2). It has a T255 spherical harmonic representation of the atmospheric dynamic and thermodynamic fields, corresponding to grid spacings of about $80 \mathrm{~km}$, on 60 vertical levels from the surface up to $0.1 \mathrm{hPa}$. Here, we use the interpolated $0.5 \times 0.5^{\circ}$ product. The reanalysis covers the period from 1979 to the near present and uses a $12 \mathrm{~h} 4 \mathrm{D}$-Var assimilation technique. The two ERA-Interim fields used in the water-balance computations (i.e. atmospheric moisture flux divergence and water vapour content) contain assimilated humidity and wind
Table 1. Correlations between BSWB v2011 and BSWB v2016 time series (drift-corrected data) of absolute TWS variations as well as of the anomalies in the river basins covered by both datasets and with at least 4 overlapping years of data.

\begin{tabular}{lcc}
\hline River & Absolute & Anomalies \\
\hline Lena at Stolb & 1.00 & 0.96 \\
Selenga at Mostovoy & 1.00 & 0.91 \\
Yenisey at Igarka & 1.00 & 0.98 \\
Irtysh at Omsk & 0.99 & 0.89 \\
Ob' at Salekhard & 0.99 & 0.91 \\
Yukon River at Pilot Station, AK & 0.98 & 0.85 \\
Columbia River at The Dalles, OR & 0.99 & 0.95 \\
Mackenzie River at Arctic Red River & 0.99 & 0.96 \\
Rhône at Beaucaire & 1.00 & 0.96 \\
Rhine River at Rees & 0.94 & 0.87 \\
Weser at Intschede & 1.00 & 0.98 \\
Elbe River at Neu Darchau & 0.97 & 0.93 \\
Volga at Volgograd power plant & 1.00 & 0.96 \\
Mean & 0.99 & 0.93 \\
\hline
\end{tabular}

observations from radiosondes. Additional documentation on ERA-Interim can be found at http://www.ecmwf.int/en/ research/climate-reanalysis/era-interim.

\subsection{Streamflow data and catchment boundaries}

The monthly streamflow data have been obtained from the Global Runoff Data Center (GRDC). We use the GRDC reference dataset (http://www.bafg.de/GRDC/EN/ 04_spcldtbss/43_GRfN/refDataset_node.html), which compiles time series of river discharge data of 718 stations of the GRDC database longer than 20 years, each capturing a basin area greater than $10000 \mathrm{~km}^{2}$. The GRDC reference dataset time series are updated regularly.

Catchment boundaries are provided by the GRDC as shape polygons. These are used to average the ERA-Interim fields over the basin area (see below).

\section{BSWB v2016 dataset}

\subsection{Processing}

The ERA-Interim atmospheric moisture flux divergence and water vapour content are processed to monthly averages first. Then these fields are averaged over the basin area using the fractional coverage of the catchments in each ERA-Interim grid cell as a weighting factor. For the basin averaging, we use the R-package "raster" (http://cran.r-project.org/web/ packages/raster/). Note that basin masks with the fraction of the grid cell inside the catchment are provided for different spatial resolutions as part of the BSWB v2016 dataset (see Sect. 7).

From the GRDC reference dataset, the monthly data are used. The flags provided are applied in the following way:

- Flag 99 (use not recommended by the provider) is set to missing data. 


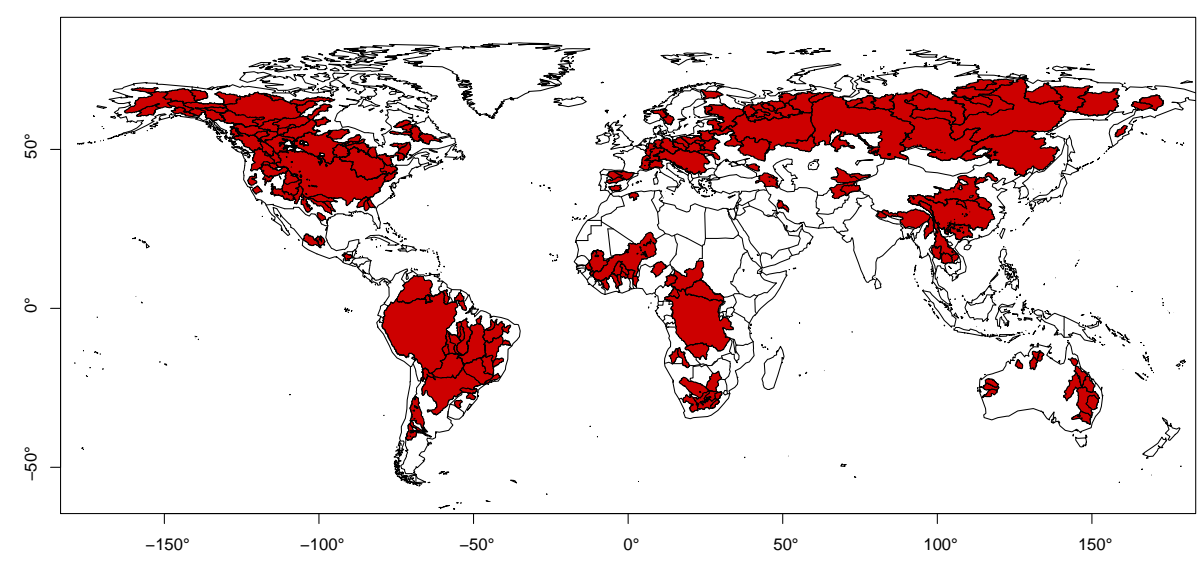

Figure 1. Global coverage of river basins of the BSWB v2016 dataset.

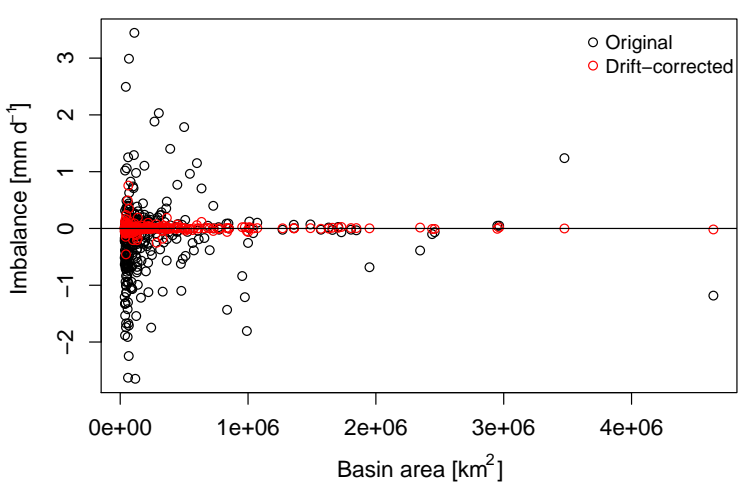

Figure 2. Long-term averages of $\{\overline{\partial S / \partial t}\}$ as indication for the imbalance vs. domain size of the basins.

- Monthly data based on more than 10 missing daily values is set to missing data.

GRDC provides two data streams as part of the reference dataset, "original" data from the data provider and "calculated" data that was modified by GRDC. As suggested by GRDC, we use the calculated values for times when they are available, otherwise the original values are used (GRDC, personal communication). Finally, the monthly variations in TWS are calculated using Eq. (3).

The critical domain size for water-balance computations using high-resolution reanalysis data is assumed to be of the order of $10^{5} \mathrm{~km}^{2}$ (Yeh et al., 1998; Berbery and Rasmusson, 1999; Seneviratne et al., 2004). Smaller basins often suffer from an imbalance between moisture convergence and streamflow (see below, and e.g. Hirschi et al., 2006a; Mueller et al., 2011). For consistency with BSWB v2011, we consider basins greater than $35000 \mathrm{~km}^{2}$.

Moreover, only basins covering more than 6 overlapping years of streamflow and reanalysis data are presented. Consequently, the BSWB v2016 dataset covers the time period 1979-2015, but is often limited by availability of streamflow data. The resulting global coverage with basins is displayed in Fig. 1. Currently, the BSWB v2016 dataset encompasses 341 river basins.

\subsection{Imbalance and drift correction}

In the long term, the water input to a basin should be balanced by the water output. As the contribution of the changes in column storage of water vapour are negligible for annual to long-term means, column integrated moisture flux convergence should be balanced by streamflow. This assumption is generally correct for multi-year means, although some regions may show persistent trends, e.g. due to groundwater withdrawal (e.g. Zektser et al., 2005; Rodell et al., 2009). Other neglected factors are inter-basin groundwater flow as well as direct groundwater discharge to the ocean. This latter term is not included in the measured streamflow and represents approximatively $6 \%$ of the total annual global water gain by the oceans (Zektser and Loaiciga, 1993).

In particular smaller river basins preferentially suffer from an imbalance between long-term means of the vertically integrated water vapour flux convergence and the streamflow of the basin. Figure 2 displays this imbalance as the longterm average of $\{\overline{\partial S / \partial t}\}$ vs. the domain size of the river basins. Our results roughly confirm the threshold for the critical domain size for water-balance computations $\left(10^{5} \mathrm{~km}^{2}\right.$, see Sect. 4.1) as the imbalance decreases above this basin size.

As a consequence of the imbalance, the temporal integration of the diagnosed monthly variations in TWS, i.e

$S(t)=S_{0}+\int_{t_{0}}^{t}\left\{\frac{\overline{\partial S}}{\partial t}\right\} \mathrm{d} t$ with $S_{0}=0 \mathrm{~mm}$,

shows a drift in TWS. The likely reason for this drift are biases in the atmospheric moisture convergence data (Seneviratne et al., 2004), though actual drifts in TWS can be important in some regions and could contribute to part of the 
(a)

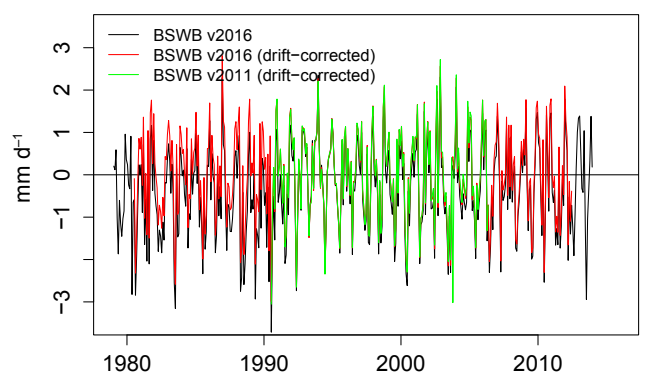

(c) Anomalies ELBE RIVER at NEU DARCHAU (no. 6340110)

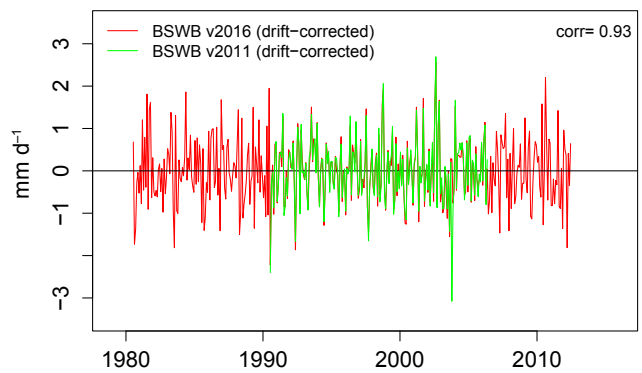

(b) RHINE RIVER at REES (no. 6335020)

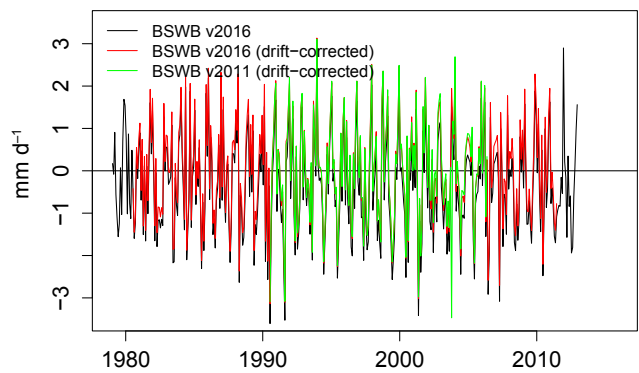

(d) Anomalies RHINE RIVER at REES (no. 6335020)

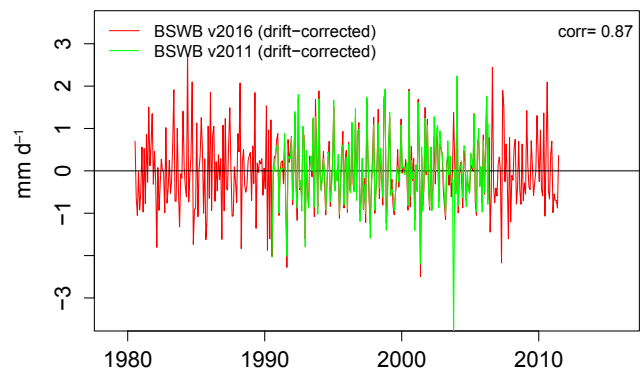

Figure 3. Comparison of BSWB v2011 and BSWB v2016 data of the Elbe (at Neu Darchau) and the Rhine (at Rees) river basins (with numbers in brackets denoting the GRDC station number). Top panels show the absolute time series and bottom panels the anomalies with respect to the mean seasonal cycle (with the correlation between the anomaly time series noted as well). For BSWB v2016, both the original and the drift-corrected data are displayed for the absolute time series.

(a) VOLGA at VOLGOGRAD POWER PLANT (no. 6977100)

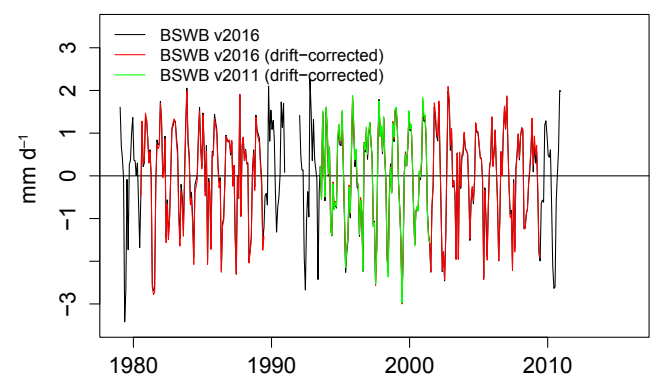

(c) Anomalies VOLGA at VOLGOGRAD POWER PLANT (no. 6977100)

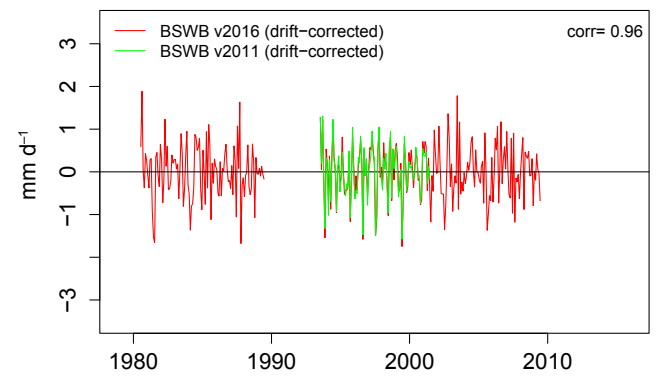

(b) COLUMBIA RIVER at THE DALLES, OR (no. 4115200 )

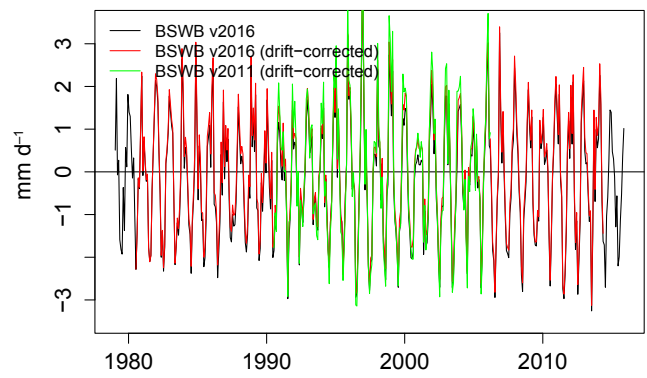

(d) Anomalies COLUMBIA RIVER at THE DALLES, OR (no. 4115200)

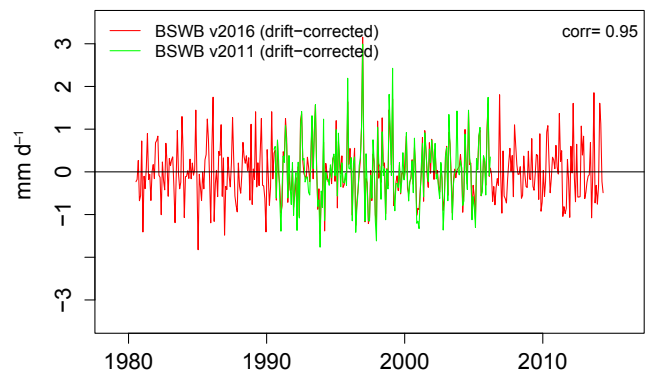

Figure 4. As Fig. 3, but for the Volga (at Volgograd power plant) and the Columbia (at The Dalles) river basins. 
(a)

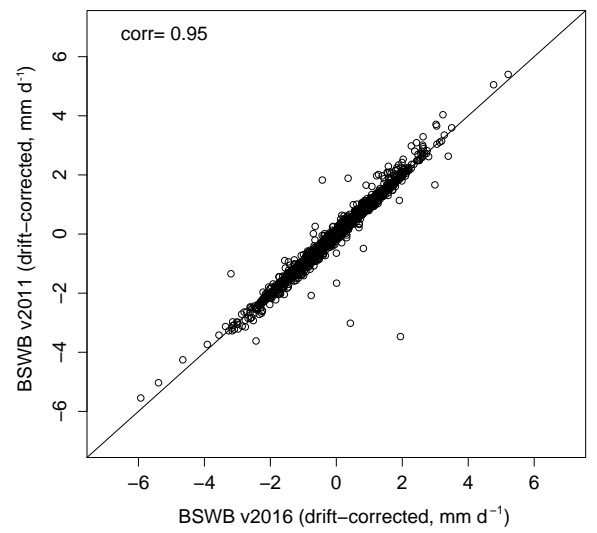

(b) Anomalies

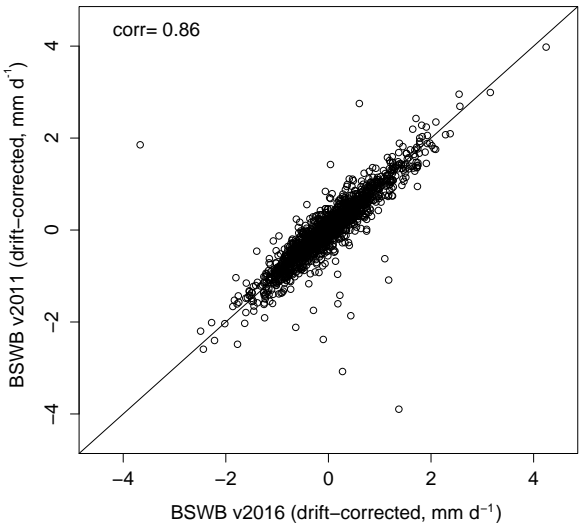

Figure 5. Scatter plots of BSWB v2011 vs. BSWB v2016; all basins covered by both datasets. (a) Absolute values of monthly TWS variations; (b) their anomalies with respect to the mean seasonal cycle.

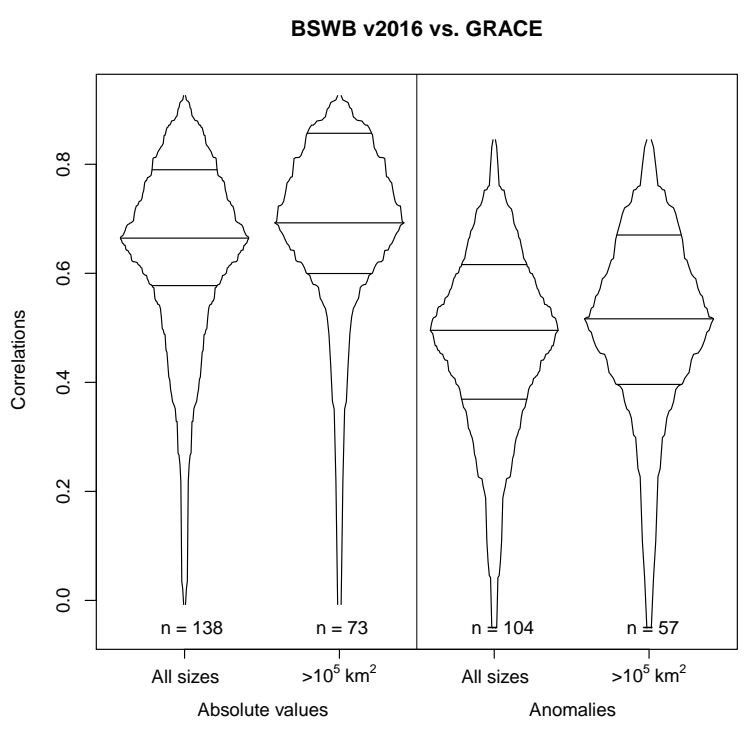

Figure 6. Box-percentile plot showing the distributions of the correlations between BSWB v2016 and GRACE time series for absolute values and for their anomalies with respect to the mean seasonal cycle. Basins with at least 4 overlapping years of data and with at least 9 years for the calculation of the mean seasonal cycle are considered, with the resulting number of basins denoted in the plot. The distributions are displayed for all basin sizes as well as for basins larger than $10^{5} \mathrm{~km}^{2}$. The width of the box at any given height is proportional to the percent of observations that are more extreme in that direction. The median and the 25 th and 75 th percentiles are marked by lines across the box.

signal (see above). The errors in the run-off measurements are expected to be small, i.e. around $5 \%$ (Winter, 1981) for longer-term averages. As widespread information on natural sources of drifts in TWS is not available, the most appropriate procedure is to assume that the observed drifts are purely artificial and to remove them by a high-pass filter.
The drift correction is achieved by subtracting a running mean with a 3-year window from the original estimates of TWS variations. This forces the long-term average of $\{\overline{\partial S / \partial t}\}$ to zero (cf. red dots in Fig. 2) and allows the removal of the artificial drift without losing the short-term variability. Note that a remaining imbalance might persist on Fig. 2 due to non-complete years of data.

We provide both the original and the drift-corrected estimates as part of the BSWB v2016 dataset. In this way, the application of alternative filters (e.g. locally weighted regression LOESS) to the original estimates is still possible for the user. Note that due to the reasons presented, the BSWB data are not applicable in trend analyses.

\section{Comparison with previous BSWB v2011}

Due to the availability of ERA-Interim and streamflow data, BSWB v2011 was restricted to the 1989-2008 time period. ERA-Interim has been updated and temporally extended since then (see http://www.ecmwf.int/en/about/media-centre/news/2011/ extension-era-interim-reanalysis-1979). In addition, the BSWB v2016 datasets relies on a consistent run-off database from GRDC (i.e. the GRDC reference dataset), while BSWB v2011 was based on various heterogeneous data sources for run-off (apart from GRDC also the US Geological Survey and local sources with varying data formatting and quality checks). By using the GRDC reference dataset, enhanced consistency between the basins can be ensured, and future updates of the BSWB dataset are more easily feasible by relying on one source for run-off only.

To check the consistency of the updated BSWB v2016 dataset with the previous BSWB v2011, we compare time series of both versions for some river basins. Note that despite the varying data sources (see above), the differences between the two dataset versions should only be minor. Figures 3 and 
4 show time series of the BSWB v2011 and BSWB v2016 datasets for selected basins. The datasets agree very well, both for the absolute TWS variations as well as for their anomalies (i.e. anomalies with respect to the mean seasonal cycle). Correlations amount to 0.99 on the average for absolute TWS variations and are mostly higher than 0.85 for the anomalies (for basins with at least 4 overlapping years of data, see Table 1). This good agreement is also visible in the scatter plots based on all basins covered by both datasets (Fig. 5), which again show high correlations between BSWB v2011 and BSWB v2016 both for absolute values and the anomalies. Despite this close agreement, differences between BSWB v2011 and BSWB v2016 exist and are likely related to changes in ERA-Interim. For instance the previously existing negative outlier in Europe in 2003 was caused by a strong moisture divergence which has been alleviated in the extended ERA-Interim version (see Fig. 3).

\section{Comparison with GRACE}

The BSWB v2016 dataset is also compared with independent remote-sensing-based estimates of TWS from GRACE (Tapley et al., 2004). We use the Jet Propulsion Laboratory (JPL)RL05M GRACE mascon (mass concentration blocks) solution, providing equivalent water thickness with a spatial sampling of $0.5 \times 0.5^{\circ}$ (doi:10.5067/TEMSC-OCL05; Watkins et al., 2015). The BSWB v2016 drift-corrected monthly variations in TWS have been temporally integrated for the comparison with GRACE (see also Sect. 4.2).

Figure 6 displays the distributions of the time series correlations between BSWB v2016 and GRACE for the absolute values as well as for their anomalies (i.e. anomalies with respect to the mean seasonal cycle) as box-percentile plots (Esty and Banfield, 2003). Basins with at least 4 overlapping years of data and with at least 9 years for the calculation of the mean seasonal cycle are considered. The analysis is done separately for all basin sizes as well as for basins larger than $10^{5} \mathrm{~km}^{2}$. The two datasets mostly agree well, with slightly higher correlations for the larger basins. Mean correlations amount to 0.7 for the absolute values and 0.51 for the anomalies.

\section{Data availability}

The basin-scale diagnostic dataset of monthly variations in terrestrial water storage (BSWB v2016) presented here is available for download at the ETH data archive: doi:10.5905/ethz-1007-82. The data are provided in individual ASCII files for each of the river basins and contain time series of the uncorrected monthly variations in terrestrial water storage (in units of $\mathrm{mm} \mathrm{d}^{-1}$ ) as well as the driftcorrected data (see Sect. 4.2). Moreover, gridded masks of the river basins are provided to facilitate comparison with other gridded data (e.g. climate model output). The masks are made available in NetCDF format for three spatial resolutions $\left(1 \times 1,0.5 \times 0.5\right.$, and $\left.0.25 \times 0.25^{\circ}\right)$ and contain the fraction of the grid cell inside the respective catchment. Older versions of the BSWB dataset are available at the following website: www.iac.ethz.ch/url/bswb.

\section{Conclusions}

We present an update of a basin-scale diagnostic dataset of monthly variations in terrestrial water storage for large river basins worldwide (BSWB v2016). The dataset is derived using a combined atmospheric and terrestrial water-balance approach with conventional streamflow measurements and atmospheric reanalysis data from ECMWF ERA-Interim. It extends the existing version of the dataset (Mueller et al., 2011) temporally and spatially (i.e. 1979-2015 vs. 1989-2008, 341 vs. 36 river basins). Overall, the update shows very good agreement with the previous version of the dataset. It also compares well with independent remote-sensing-based estimates of TWS. BSWB data proved to be valuable for climate and land-surface model evaluation (e.g. van den Hurk et al., 2005; Hirschi et al., 2007; Balsamo et al., 2009; Dutra et al., 2010) and the investigation of land-surface processes (e.g. Fischer et al., 2007), as well as for the evaluation of other large-scale estimates of TWS (e.g. Hirschi et al., 2006b; Troch et al., 2007).

Competing interests. The authors declare that they have no conflict of interest.

Acknowledgements. We thank ECMWF for providing the atmospheric reanalysis data and GRDC for the run-off data. GRACE land mass grids were processed by the Jet Propulsion Laboratory (JPL) GRACE Team and are available at http://grace.jpl.nasa.gov, supported by the NASA MEaSUREs Program. We thank Vincent Humphrey for help with the GRACE data. Partial support from the ERC DROUGHT-HEAT project (grant agreement FP7-IDEASERC-617518) is acknowledged.

Edited by: D. Carlson

Reviewed by: two anonymous referees

\section{References}

Balsamo, G., Viterbo, P., Beljaars, A., van den Hurk, B., Hirschi, M., Betts, A. K., and Scipal, K.: A revised hydrology for the ECMWF model: Verification from field site to terrestrial water storage and impact in the Integrated Forecast System, J. Hydrometeorol., 10, 623-643, doi:10.1175/2008JHM1068.1, 2009.

Beljaars, A. C. M., Viterbo, P., Miller, M. J., and Betts, A. K.: The anomalous rainfall over the United States during July 1993: Sensitivity to land surface parameterization and soil moisture anomalies, Mon. Weather Rev., 124, 362-383, 1996. 
Berbery, E. H. and Rasmusson, E. M.: Mississippi moisture budgets on regional scale, Mon. Weather Rev., 127, 2654-2673, 1999.

Dee, D. P., Uppala, S. M., Simmons, A. J., Berrisford, P., Poli, P., Kobayashi, S., Andrae, U., Balmaseda, M. A., Balsamo, G., Bauer, P., Bechtold, P., Beljaars, A. C. M., van de Berg, L., Bidlot, J., Bormann, N., Delsol, C., Dragani, R., Fuentes, M., Geer, A. J., Haimberger, L., Healy, S. B., Hersbach, H., Holm, E. V., Isaksen, L., Kallberg, P., Kohler, M., Matricardi, M., McNally, A. P., Monge-Sanz, B. M., Morcrette, J. J., Park, B. K., Peubey, C., de Rosnay, P., Tavolato, C., Thepaut, J. N., and Vitart, F.: The ERA-Interim reanalysis: configuration and performance of the data assimilation system, Q. J. Roy. Meteor. Soc., 137, 553-597, doi:10.1002/qj.828, 2011.

Dorigo, W. A., Xaver, A., Vreugdenhil, M., Gruber, A., Hegyiová, A., Sanchis-Dufau, A. D., Zamojski, D., Cordes, C., Wagner, W., and Drusch, M.: Global Automated Quality Control of In Situ Soil Moisture Data from the International Soil Moisture Network, Vadose Zone J., 12, doi:10.2136/vzj2012.0097, 2013.

Drusch, M.: Initializing numerical weather prediction models with satellite-derived surface soil moisture: Data assimilation experiments with ECMWF's Integrated Forecast System and the TMI soil moisture data set, J. Geophys. Res., 112, D03102, doi:10.1029/2006JD007478, 2007.

Dutra, E., Balsamo, G., Viterbo, P., Miranda, P. M. A., Beljaars, A., Schär, C., and Elder, K.: An Improved Snow Scheme for the ECMWF Land Surface Model: Description and Offline Validation, J. Hydrometeorol., 11, 899-916, doi:10.1175/2010JHM1249.1, 2010.

Esty, W. and Banfield, J.: The Box-Percentile Plot, J. Stat. Softw., 8, 1-14, doi:10.18637/jss.v008.i17, 2003.

Fischer, E. M., Seneviratne, S. I., Vidale, P. L., Lüthi, D., and Schär, C.: Soil moisture-atmosphere interactions during the 2003 European summer heatwave, J. Climate, 20, 5081-5099, doi:10.1175/JCLI4288.1, 2007.

Guillod, B. P., Orlowsky, B., Miralles, D. G., Teuling, A. J., and Seneviratne, S. I.: Reconciling spatial and temporal soil moisture effects on afternoon rainfall, Nat. Commun., 6, 6443, doi:10.1038/ncomms7443, 2015.

Hirschi, M., Seneviratne, S. I., and Schär, C.: Seasonal variations in terrestrial water storage for major midlatitude river basins, $\mathrm{J}$. Hydrometeorol., 7, 39-60, 2006a.

Hirschi, M., Viterbo, P., and Seneviratne, S. I.: Basin-scale waterbalance estimates of terrestrial water storage variations from ECMWF operational forecast analysis, Geophys. Res. Lett., 33, L21401, doi:10.1029/2006GL027659, 2006b.

Hirschi, M., Seneviratne, S. I., Hagemann, S., and Schär, C.: Analysis of seasonal terrestrial water storage variations in regional climate simulations over Europe, J. Geophys. Res., 112, D22109, doi:10.1029/2006JD008338, 2007.

Hirschi, M., Seneviratne, S. I., Alexandrov, V., Boberg, F., Boroneant, C., Christensen, O. B., Formayer, H., Orlowsky, B., and Stepanek, P.: Observational evidence for soil-moisture impact on hot extremes in southeastern Europe, Nat. Geosci., 4, 17-21, doi:10.1038/ngeo1032, 2011.

Humphrey, V., Gudmundsson, L., and Seneviratne, S. I.: Assessing Global Water Storage Variability from GRACE: Trends, Seasonal Cycle, Subseasonal Anomalies and Extremes, Surv. Geophys., 37, 357-395, doi:10.1007/s10712-016-9367-1, 2016.
Koster, R. D., Suarez, M. J., and Heiser, M.: Variance and predictability of precipitation at seasonal-to-interannual timescales, J. Hydrometeorol., 1, 26-46, 2000.

Koster, R. D., Guo, Z., Dirmeyer, P. A., Bonan, G., Chan, E., Cox, P., Davies, H., Gordon, C. T., Kanae, S., Kowalczyk, E., Lawrence, D., Liu, P., Lu, C. H., Malyshev, S., McAvaney, B., Mitchell, K., Mocko, D., Oki, T., Oleson, K. W., Pitman, A., Sud, Y. C., Taylor, C. M., Verseghy, D., Vasic, R., Xue, Y., and Yamada, T.: GLACE: The Global Land-Atmosphere Coupling Experiment. Part I: Overview, J. Hydrometeorol., 7, 590-610, 2006.

Koster, R. D., Guo, Z., Yang, R., Dirmeyer, P. A., Mitchell, K., and Puma, M. J.: On the Nature of Soil Moisture in Land Surface Models, J. Climate, 22, 4322-4335, 2009.

Liu, Y., Dorigo, W., Parinussa, R., de Jeu, R., Wagner, W., McCabe, M., Evans, J., and van Dijk, A.: Trend-preserving blending of passive and active microwave soil moisture retrievals, Remote Sens. Environ., 123, 280-297, doi:10.1016/j.rse.2012.03.014, 2012.

Milly, P. C. D. and Dunne, K. A.: Sensitivity of the global water cycle to the water-holding capacity of the land, J. Climate, 7, 506-526, 1994.

Miralles, D. G., Teuling, A. J., van Heerwaarden, C. C., and VilaGuerau de Arellano, J.: Mega-heatwave temperatures due to combined soil desiccation and atmospheric heat accumulation, Nat. Geosci., 7, 345-349, doi:10.1038/ngeo2141, 2014.

Mueller, B., Hirschi, M., and Seneviratne, S. I.: New diagnostic estimates of variations in terrestrial water storage based on ERA-Interim data, Hydrol. Process., 25, 996-1008, doi:10.1002/hyp.7652, 2011.

Orth, R., Dutra, E., and Pappenberger, F.: Improving Weather Predictability by Including Land Surface Model Parameter Uncertainty, Mon. Weather Rev., 144, 1551-1569, doi:10.1175/MWRD-15-0283.1, 2016.

Owe, M. and Van de Griend, A. A.: Comparison of soil moisture penetration depths for several bare soils at two microwave frequencies and implications for remote sensing, Water Resour. Res., 34, 2319-2327, doi:10.1029/98WR01469, 1998.

Peixoto, J. P. and Oort, A. H.: Physics of climate, AIP Press, New York, 1992.

Ramillien, G., Famiglietti, J., and Wahr, J.: Detection of Continental Hydrology and Glaciology Signals from GRACE: A Review, Surv. Geophys., 29, 361-374, 2008.

Rasmusson, E. M.: Atmospheric Water Vapor Transport and the Water Balance of North America. II. Large-scale water balance investigations, Mon. Weather Rev., 96, 720-734, 1968.

Rodell, M., Velicogna, I., and Famiglietti, J. S.: Satellite-based estimates of groundwater depletion in India, Nature, 460, 999-1002, doi:10.1038/nature08238, 2009.

Seneviratne, S. I., Viterbo, P., Lüthi, D., and Schär, C.: Inferring changes in terrestrial water storage using ERA-40 reanalysis data: The Mississippi river basin, J. Climate, 17, 2039-2057, 2004.

Seneviratne, S. I., Lüthi, D., Litschi, M., and Schär, C.: Landatmosphere coupling and climate change in Europe, Nature, 443 205-209, doi:10.1038/nature05095, 2006.

Seneviratne, S. I., Corti, T., Davin, E. L., Hirschi, M., Jaeger, E. B., Lehner, I., Orlowsky, B., and Teuling, A. J.: Investigating soil moisture-climate interactions in a 
changing climate: A review, Earth-Sci. Rev., 99, 125-161, doi:10.1016/j.earscirev.2010.02.004, 2010.

Seneviratne, S. I., Wilhelm, M., Stanelle, T., van den Hurk, B., Hagemann, S., Berg, A., Cheruy, F., Higgins, M. E., Meier, A., Brovkin, V., Claussen, M., Ducharne, A., Dufresne, J.-L., Findell, K. L., Ghattas, J., Lawrence, D. M., Malyshev, S., Rummukainen, M., and Smith, B.: Impact of soil moistureclimate feedbacks on CMIP5 projections: First results from the GLACE-CMIP5 experiment, Geophys. Res. Lett., 40, 52125217, doi:10.1002/grl.50956, 2013.

Shukla, J. and Mintz, Y.: Influence of land-surface evaporation on the earth's climate, Science, 215, 1498-1501, 1982.

Tapley, B. D., Bettadpur, S., Ries, J. C., Thompson, P. F., and Watkins, M. M.: GRACE measurements of mass variability in the Earth system, Science, 305, 503-505, 2004.

Troch, P., Durcik, M., Seneviratne, S., Hirschi, M., Teuling, A., Hurkmans, R., and Hasan, S.: New Data Sets to Estimate Terrestrial Water Storage Change, EOS, 88, 469-470, 2007.

van den Hurk, B., Hirschi, M., Schär, C., Lenderink, G., van Meijgaard, E., van Ulden, A., Rockel, B., Hagemann, S., Graham, P., Kjellström, E., and Jones, R.: Soil control on runoff response to climate change in regional climate model simulations, J. Climate, 18, 3536-3551, 2005. van den Hurk, B., Doblas-Reyes, F., Balsamo, G., Koster, R., Seneviratne, S., and Camargo, H.: Soil moisture effects on seasonal temperature and precipitation forecast scores in Europe, Clim. Dynam., 38, 349-362, doi:10.1007/s00382-010-0956-2, 2010.

Watkins, M. M., Wiese, D. N., Yuan, D.-N., Boening, C., and Landerer, F. W.: Improved methods for observing Earth's time variable mass distribution with GRACE using spherical cap mascons, J. Geophys. Res., 120, 2648-2671, doi:10.1002/2014JB011547, 2015.

Winter, T. C.: Uncertainties in estimating the water balance of lakes, Water Resour. Bull., 17, 82-115, 1981.

Yeh, P. J.-F., Irizarry, M., and Eltahir, E. A. B.: Hydroclimatology of Illinois: A comparison of monthly evaporation estimates based on atmospheric water balance and soil water balance, J. Geophys. Res., 103, 19823-19837, 1998.

Zektser, I. S. and Loaiciga, H. A.: Groundwater fluxes in the global hydrologic cycle: past, present and future, J. Hydrol., 144, 405427, 1993.

Zektser, I. S., Loaiciga, H. A., and Wolf, J. T.: Environmental impacts of groundwater overdraft: selected case studies in the southwestern United States, Environ. Geol., 47, 396-404, 2005. 